\title{
Alcohol Promotes Dopamine Release in the Human Nucleus Accumbens
}

\author{
ISABELLE BOILEAU, ${ }^{1}$ JEAN-MARC ASSAAD, ${ }^{2,4}$ ROBERT O. PIHL, ${ }^{2}$ CHAWKI BENKELFAT, ${ }^{3}$ \\ MARCO LEYTON, ${ }^{3}$ MIRKO DIKSIC, ${ }^{1}$ RICHARD E. TREMBLAY, ${ }^{4}$ AND ALAIN DAGHER ${ }^{1 *}$ \\ ${ }^{1}$ McConnell Brain Imaging Centre, Montreal Neurological Institute, McGill University, Montréal, QC, Canada \\ ${ }^{2}$ Department of Psychology, McGill University, Montréal, QC, Canada \\ ${ }^{3}$ Department of Psychiatry, McGill University, Montréal, QC, Canada \\ ${ }^{4}$ Research Unit on Children's Psychosocial Maladjustment, Université de Montréal, Montréal, QC, Canada
}

KEY WORDS PET; $\left[{ }^{11} \mathrm{C}\right]$ raclopride; addiction; personality; impulsivity; heart rate; CNS stimulants

\begin{abstract}
Microdialysis experiments in rodents indicate that ethanol promotes dopamine release predominantly in the nucleus accumbens, a phenomenon that is implicated in the reinforcing effects of drugs of abuse. The aim of the present study was to test the hypothesis in humans that an oral dose of ethanol would lead to dopamine release in the ventral striatum, including the nucleus accumbens. Six healthy subjects underwent two $\left[{ }^{11} \mathrm{C}\right]$ raclopride PET scans following either alcohol $(1 \mathrm{ml} / \mathrm{kg})$ in orange juice or orange juice alone. Subjective mood changes, heart rate, and blood-alcohol levels were monitored throughout the procedure. Personality traits were evaluated using the tridimensional personality questionnaire. PET images were co-registered with MRI and transformed into stereotaxic space. Statistical parametric maps of $\left[{ }^{11} \mathrm{C}\right]$ raclopride binding potential change were generated. There was a significant reduction in $\left[{ }^{11} \mathrm{C}\right]$ raclopride binding potential bilaterally in the ventral striatum/nucleus accumbens in the alcohol condition compared to the orange juice condition, indicative of increased extracellular dopamine. Moreover, the magnitude of the change in $\left[{ }^{11} \mathrm{C}\right]$ raclopride binding correlated with the alcohol-induced increase in heart rate, which is thought to be a marker of the psychostimulant effects of the drug, and with the personality dimension of impulsiveness. The present study is the first report that, in humans, alcohol promotes dopamine release in the brain, with a preferential effect in the ventral striatum. These findings support the hypothesis that mesolimbic dopamine activation is a common property of abused substances, possibly mediating their reinforcing effects. Synapse 49:

226-231, 2003. @ 2003 Wiley-Liss, Inc.
\end{abstract}

\section{INTRODUCTION}

Addiction is thought to result in large part from the reinforcing properties of drugs of abuse on brain reward systems, and in particular on mesolimbic dopamine (Koob et al., 1998; Wise, 1996). Microdialysis studies in rats show that ethanol and other drugs of abuse, such as opiates, nicotine, amphetamine, and cocaine, acutely increase extracellular dopamine levels predominantly in the nucleus accumbens (NAc) (Di Chiara and Imperato, 1988). The role of NAc dopamine in alcohol self-administration is further supported by reports of changes in consumption following alterations in mesolimbic dopamine neurotransmission (Rassnick et al., 1993; Samson et al., 1993; Nowak et al., 2000), ethanol self-administration into the ventral tegmental area (Gatto et al., 1994), and alcohol withdrawal-induced reductions in both dopamine neuron firing and NAc extracellular dopamine concentration (Rossetti et al., 1992; Diana et al., 1992) that are reversed by ethanol administration (Weiss et al., 1996). Alcohol is widely abused by humans; however, no studies have directly investigated the effect of alcohol consumption on the dopamine system. We now present, for the first time in humans, evidence that alcohol consumed orally promotes dopamine release specifically in the NAc.

We measured dopamine release in response to a single-dose administration of alcohol using positron emis-

Contract grant sponsors: the Canadian Institutes for Health Research and the Fonds de la Recherche en Santé du Québec.

*Correspondence to: Alain Dagher, Montreal Neurological Institute, 3801 University St., Montréal (QC), Canada, H3A 2B4.

E-mail: alain@bic.mni.mcgill.ca

Received 31 January 2003; Accepted 4 April 2003

DOI 10.1002/syn.10226 
sion tomography (PET) and the dopamine receptor ligand $\left[{ }^{11} \mathrm{C}\right]$ raclopride. We used a two-scan method based on evidence in primates, including combined PET microdialysis studies, that the binding of benzamides such as $\left[{ }^{11} \mathrm{C}\right]$ raclopride is sensitive and proportional to extracellular dopamine concentration in the striatum (Endres et al., 1997; Ginovart et al., 1997; Hartvig et al., 1997; Laruelle et al., 1997; Laruelle, 2000). This approach has been used in humans to measure the dopamine response to psychostimulants (Carson et al., 1997; Schlaepfer et al., 1997; Volkow et al., 2001) and behavioral tasks (Koepp et al., 1998). Three recent PET studies have also shown that dopamine release following amphetamine occurs mostly in the ventral striatum and that the amount of dopamine released correlates with self-reported behavioral measures of euphoria or drug wanting (Drevets et al., 2001; Leyton et al., 2002; Martinez et al., 2003).

\section{MATERIALS AND METHODS}

Seven healthy male nonalcoholic moderate drinkers (brief Michigan Alcoholism Screening Test, Pokorny et al., 1972), age $22( \pm 0.6)$, were recruited from an existent longitudinal cohort (Tremblay et al., 1994). All subjects who participated had experienced the alcohol dose administered in this study at least twice in a laboratory setting. Data from one of the seven subjects had to be excluded due to excessive motion during the scan. All subjects were free of active or past medical or psychiatric illness. Subjects fasted and abstained from caffeine or tobacco for a minimum of $4 \mathrm{~h}$ before each test session. Five of the six subjects were nonsmokers and one was a light smoker (1-2 cigarettes per day). They were also asked to refrain from taking drugs for 7 days and alcohol for $24 \mathrm{~h}$ prior to each experimental day. Before each scanning session, subjects underwent screening for drugs of abuse (Triage Panel for Drugs of Abuse, Biosite Diagnostics, San Diego, CA) including alcohol (Alcosensor III intoxicometer, Thomas Instruments, Montreal, QC). All subjects read and signed a consent form approved by the Research and Ethics Committee of the Montreal Neurological Institute.

Subjects participated in two $\left[{ }^{11} \mathrm{C}\right]$ raclopride PET scans after consumption of alcohol in orange juice or orange juice alone (Fig. 1). Subjects were only told about drink content (alcohol or orange juice alone) at the beginning of the session, and they did not come into contact with the drink until the time of consumption. PET data acquisition was performed at the same time of day (between 14:00 and 16:00) on separate days, 1 week apart, and counterbalanced for order of administration of alcohol (three out of six received alcohol on the first day, randomly chosen). Prior to scanning, a venous catheter was inserted in the subject's left arm. Oral consumption of alcohol ( $1 \mathrm{ml} / \mathrm{kg}$ of $95 \%$ USP alcohol over $15 \mathrm{~min}$ ) or alcohol-free mixture started $30 \mathrm{~min}$ prior to tracer injection. The dose of alcohol was se-

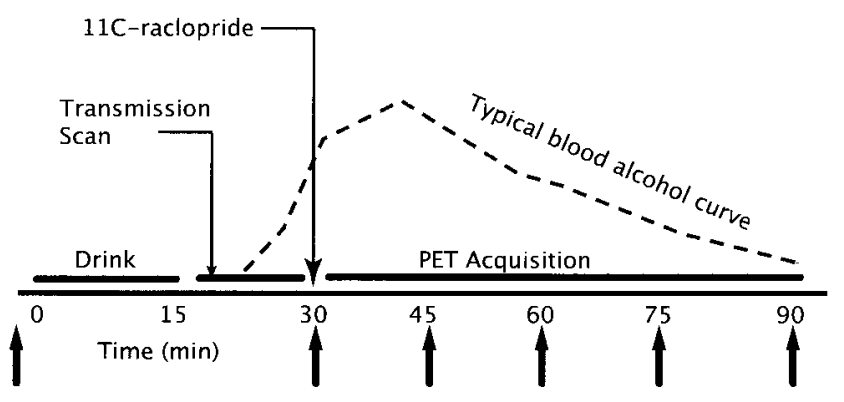

Fig. 1. Study design. The vertical arrows indicate the time points of blood sampling, subjective mood assessments, and physiological measurements.

lected based on previous behavioral experiments showing that it was intoxicating but without significant adverse effects in this population. At the end of consumption, subjects were immediately positioned in the scanner and a 12-min transmission scan was acquired using a ${ }^{68} \mathrm{Ge}$ source for the purpose of attenuation correction. Following the transmission scan, and 15 min after the end of alcohol consumption, $\left[{ }^{11} \mathrm{C}\right]$ raclopride $10 \mathrm{mCi}$ was injected as a bolus into the antecubital vein, after which PET dynamic acquisition (63 slices, 26 time frames of $60 \mathrm{~min}$ total duration) was performed.

Subjects were scanned on the CTI/Siemens ECAT HR + PET camera with lead septa removed, with intrinsic resolution $4.8 \times 4.8 \times 5.6 \mathrm{~mm}$ FWHM. Blood samples, for plasma alcohol measurements, were withdrawn from the venous cannula before the initiation of drinking, at tracer injection (15 min after finishing drinking), and every 15 min thereafter. Subjective effects of alcohol, assessed with the Subjective High Assessment Scale (SHAS, Judd et al., 1977; Schuckit et al., 1997), and heart rate were measured prior to alcohol consumption and throughout the procedure. The SHAS is a visual analog scale that assesses sensations such as feeling high, drunk, and drowsy. In a separate session, prior to the first scan, all subjects completed the tridimensional personality questionnaire (TPQ; Cloninger et al., 1991). This test assesses three dimensions of personality, including novelty seeking (impulsive, excitable, exploratory temperament), which is thought to depend in significant part on activity in the dopamine pathways (Cloninger, 1994). For the purpose of anatomical co-registration, subjects also underwent a $1 \times 1 \times 1 \mathrm{~mm}$ anatomical $T_{1}$-weighted MRI of the whole brain using a gradient echo pulse sequence $\left(\mathrm{TR}=9.7 \mathrm{~ms}, \mathrm{TE}=4 \mathrm{~ms}\right.$, flip angle $=12^{\circ}, \mathrm{FOV}=250$, matrix $=256 \times 256$ ).

PET frames were summed across time, co-registered with the corresponding MRI (Woods et al., 1993), and transformed into standardized stereotaxic space (Talairach and Tournoux, 1988) by means of automated feature-matching to the MNI template (Collins et al., 1994). Voxelwise $\left[{ }^{11} \mathrm{C}\right]$ raclopride binding potential (BP) 


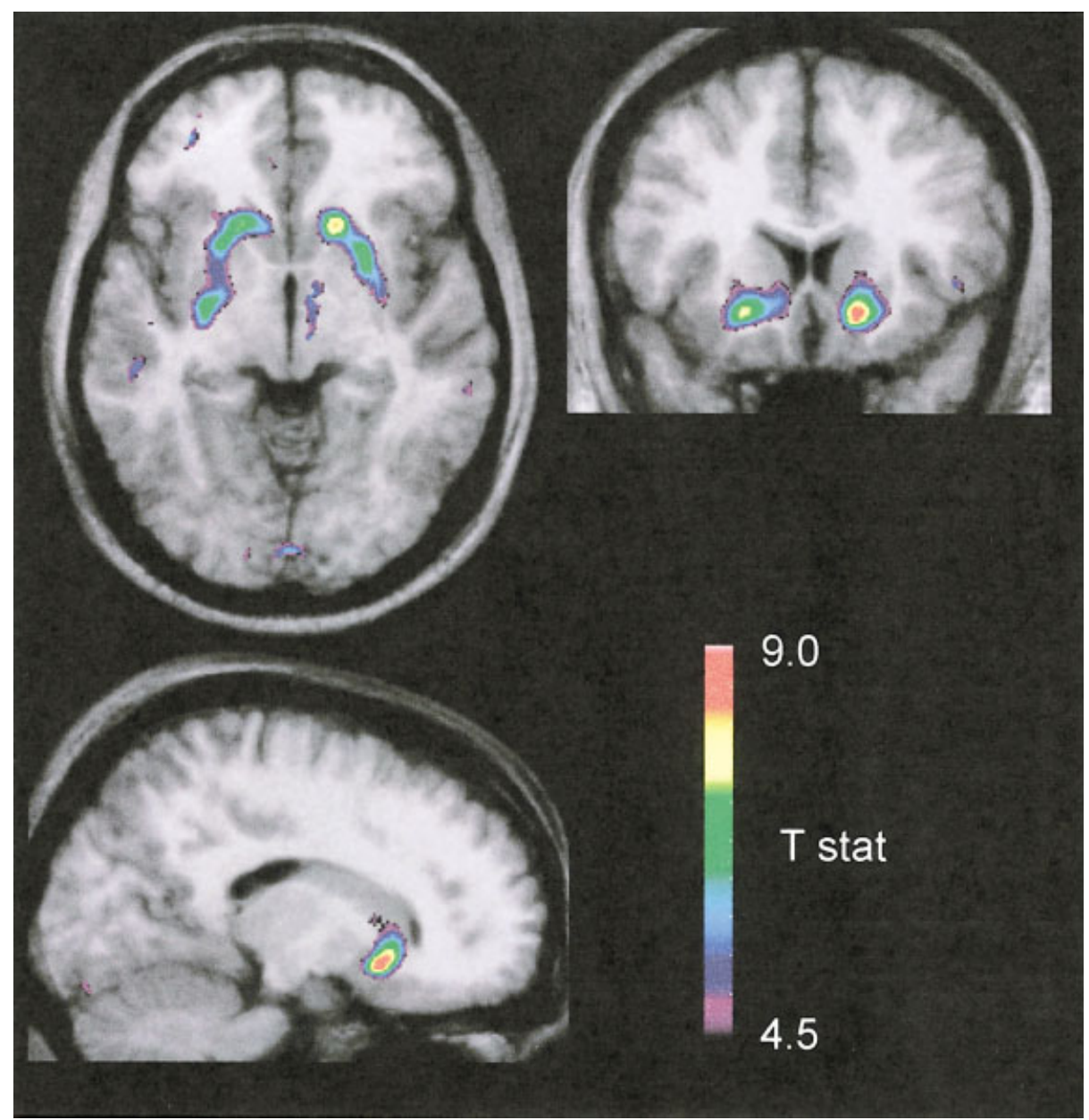

Fig. 2. Statistical t-map of the change in $\left[{ }^{11} \mathrm{C}\right]$ raclopride $\mathrm{BP}$ induced by an acute oral dose of alcohol $(1 \mathrm{ml} /$ $\mathrm{kg})$ in healthy volunteers $(\mathrm{n}=6)$. Color clusters superimposed on the average MRI from all subjects depict a significant change in BP in the ventral striatum. was calculated using a simplified reference tissue method (Lammertsma et al., 1996; Gunn et al., 1997) to generate statistical parametric images of the change in binding (Aston et al., 2000). BP values for each subject were extracted from regions of interest (ROI) manually drawn on the co-registered MRI on the left and right caudate (drawn on transverse slices at Talairach-space $z$ coordinate from +2 to $+15 \mathrm{~mm}$ ), putamen $(+2$ to $+10 \mathrm{~mm})$, ventral putamen $(-8$ to -4 $\mathrm{mm}), \mathrm{NAc}(-8$ to $-4 \mathrm{~mm})$, and cerebellum, which was used as the reference region. BP values extracted from ROI during alcohol and control scans were analyzed using a three-way ANOVA for dependent samples [Treatment $\times$ ROI $\times$ hemisphere]. Sphericity was assessed with the Mauchly test and, when indicated, corrections were made with Greenhouse-Geisser adjustments. When appropriate, least significant difference $t$-tests, Bonferroni corrected, were applied to determine the significance of regional differences in BP between the alcohol and orange juice conditions. Heart rate during the ascending part of the blood alcohol curve was compared to a baseline taken just prior to the study session. Since one subject exhibited a change in heart rate during the test session with orange juice that was greater than $2 \mathrm{SD}$ from the sample mean, magnitude of heart rate change was analyzed with the nonparametric Wilcoxon matched pairs test. Maximum change in SHAS rating from baseline taken on the same day $\left(\Delta_{\max }\right.$ [SHAS]) was used to evaluate the subjective effects of alcohol and control drinks. A $t$-test for paired samples was used to determine the difference between $\Delta_{\max }$ [SHAS] for the alcohol condition and $\Delta_{\max }$ [SHAS] for the control. Stepwise linear regression analysis was used to examine whether percent change in ROI BP could be predicted by changes in heart rate, change in SHAS scores, or TPQ personality ratings.

\section{RESULTS}

Screening for drugs of abuse was positive for only one subject (THC and trace cocaine prior to both scan conditions). Therefore, two different analyses were carried out, one excluding the data from this subject. In both cases, receptor parametric mapping identified significant reductions in $\left[{ }^{11} \mathrm{C}\right]$ raclopride $\mathrm{BP}$ in bilateral ventral striatum in the alcohol compared to the alcoholfree condition (Fig. 2). In the statistically generated 


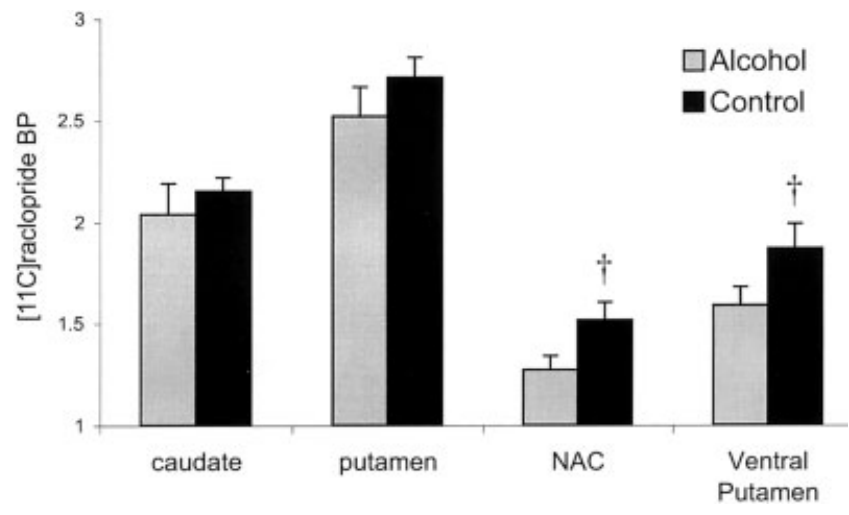

Fig. 3. Mean $\left[{ }^{11} \mathrm{C}\right]$ raclopride BP in the alcohol and control (orange juice) conditions. The data are extracted from manually drawn ROI on each subject's MRI. Bonferroni corrected pairwise comparisons: $†$ Difference between alcohol and control, $P<0.001$. Error bars represent the SEM.

t-map, $\left[{ }^{11} \mathrm{C}\right]$ raclopride $\mathrm{BP}$ values were $16.8 \pm 16.3 \%$ lower on the test day with alcohol, compared to orange juice $(\mathrm{t}(5)=2.54, P=0.05)$.

Analyses of $\left[{ }^{11} \mathrm{C}\right]$ raclopride $\mathrm{BP}$ values in the a priori defined ROI supported the receptor parametric mapping analyses (Fig. 3). A treatment $\times$ ROI $\times$ hemisphere ANOVA yielded a main effect of $\operatorname{ROI}(F(3,15)=$ $42.55, P<0.001$, Greenhouse-Geisser corrected) and a treatment $\times$ ROI interaction $(\mathrm{F}(3,15)=3.21, P=0.05)$. Bonferroni-corrected pairwise comparisons confirmed that alcohol significantly reduced BP in the NAc $(P=$ $0.003)$ and ventral putamen $(P=0.001)$ but not in the caudate $(P=0.98)$ or putamen $(P=0.84)$. The percent change in $\left[{ }^{11} \mathrm{C}\right]$ raclopride $\mathrm{BP}$ also varied with ROI $(\mathrm{F}(3,15)=13,50, P=0.001)$. In both the nucleus accumbens $(15.0 \pm 15.9 \%)$ and the ventral putamen $(13.7 \pm 16.4 \%)$, the percent decreases in $\left[{ }^{11} \mathrm{C}\right]$ raclopride $\mathrm{BP}$ were greater than those seen in either the putamen $(5.2 \pm 17.5 \%)$ or caudate nucleus $(4.0 \pm 16.4 \%)(P<$ $0.01)$.

The blood alcohol level reached a mean peak of 18.10 $( \pm 1.4) \mathrm{mmol} / \mathrm{L}(0.0833 \mathrm{gm} \%)$ at $30 \mathrm{~min}$ after drinking. During the expected ascending phase of the blood alcohol curve (15-30 min post drink) alcohol consumption resulted in small but consistent increases in heart rate $(5.47 \pm 6$ beats $/ \mathrm{min} ; \mathrm{t}(5)=1.85, P=0.12 ; 6 / 6$ subjects higher during alcohol test, Wilcoxon matched pairs test, $\mathrm{z}=2.20 ; P=0.028$ ) and self-reported feelings of "high" and "drunkenness" (paired $t$-test, $\Delta_{\max }$ [SHAS] alcohol vs. $\Delta_{\max }$ [SHAS] orange juice, $P<0.01$ ). A stepwise linear regression showed that impulsiveness, one of the subscales on the novelty-seeking dimension of the TPQ, and heart rate increase recorded at $30 \mathrm{~min}$ (i.e., during the ascending phase of the blood alcohol curve) were the only predictors of $\mathrm{BP}$ change in the ventral striatum $(\mathrm{r}=0.985 ; P=0.005)$. Neither the subjective intoxication measures nor the peak blood alcohol level correlated with the change in $\left[{ }^{11} \mathrm{C}\right]$ raclopride $\mathrm{BP}$ in any region.

\section{DISCUSSION}

The observed reduction in $\left[{ }^{11} \mathrm{C}\right]$ raclopride $\mathrm{BP}$ confined to the ventral part of the striatum is indicative of dopamine release specifically in the NAc and ventral putamen in response to alcohol in humans. The ventral specificity of the effect is consistent with three other $\left[{ }^{11} \mathrm{C}\right]$ raclopride PET studies, in which amphetamine was found to preferentially induce dopamine release in the ventral striatum in humans (Drevets et al., 2001; Leyton et al., 2002; Martinez et al., 2003). In animals, in vivo microdialysis studies have also shown a propensity for alcohol to induce dopamine release in the ventral striatum. Di Chiara and Imperato (1988) found that ethanol at rewarding doses had an almost 10-fold greater effect on dopamine release in the NAc than in the dorsal caudate. Moreover, low doses of ethanol produce a dose-dependent increase in the firing rate of A10 dopamine neurons in the ventral tegmental area, which project to the ventral striatum (Gessa et al., 1985). Activation of A9 dopamine neurons, which project to the dorsal striatum, only occurs at 5 -fold greater ethanol doses.

While a direct pharmacological effect of alcohol could account for our findings, it is possible that conditioned cues and anticipation also played a role in enhancing dopamine release. In humans, exposure to the odor of alcohol leads to autonomic nervous system activity (Stormark et al., 1995), and alcohol-related cues have been shown to cause dopamine release in rats previously trained to self-administer alcohol (Katner and Weiss, 1999). The subjects in our study only learned whether they would receive alcohol or not when they arrived at the lab and they were kept away from the drinks until the start of consumption, thus limiting the potential influence of anticipation in this experiment.

The dorsal and ventral striatum can be separated functionally and anatomically (Moore and Bloom, 1978; Heimer et al., 1982; Haber et al., 2000). Their dopamine innervations originate in different cell groups in the midbrain and their cortical connections likely account for their different functional roles. The ventral striatum, including the NAc and ventral putamen, belong to the "limbic" cortico-striatal loop that includes the amygdala, hippocampus, orbito-frontal cortex, and cingulate cortex, structures involved in emotional behavior and reward processing. There is much evidence for specific involvement of ventral striatal, or mesolimbic, dopamine in the reinforcing effects of addictive drugs (Wise, 1996; Koob et al., 1998). It is thought to mediate associative learning, whereby drug-related cues acquire incentive value (Di Chiara et al., 1999). Conditioned place preference, a laboratory test of conditioned incentive learning, is abolished by lesions or dopamine blockade of the ventral but not dorsal striatum (Everitt et al., 1991; Hiroi and White, 1991). Our finding of dopamine release confined to the ventral striatum after oral ingestion of an intoxicating dose of 
alcohol may therefore account at least in part for its addictive properties in humans.

Ethanol most likely acts on dopamine neurons indirectly (Yim et al., 1998). It potentiates GABA-A receptor function (Weiner et al., 1994) to cause inhibition of GABAergic interneurons in the substantia nigra reticulata (Mereu and Gessa, 1985), which leads to disinhibition and increased burst firing of dopamine neurons (Grace and Bunney, 1985). As stated above, A10 neurons projecting to the ventral striatum appear to be more sensitive to these systemic effects of ethanol than A9 dopamine neurons projecting to the dorsal striatum (Gessa et al., 1985). Opioid peptides may also be involved in the dopamine releasing actions of ethanol (Acquas et al., 1993; Benjamin et al., 1993; Gonzales et al., 1998).

The level of dopaminergic responsiveness in the NAc has been proposed as a marker of individual vulnerability to drug addiction. Numerous studies in rats have linked the propensity to self-administer drugs to enhanced dopamine release in the NAc in response to psychostimulants or stress (e.g., Piazza et al., 1991; Hooks et al., 1992; Zocchi et al., 1998; Marinelli and White, 2000), or ethanol (Weiss et al., 1993). In light of these studies, our finding of a correlation between the change in $\left[{ }^{11} \mathrm{C}\right]$ raclopride $\mathrm{BP}$ in response to alcohol and two variables, the alcohol-induced increase in heart rate and the personality trait of impulsiveness, is interesting.

In humans, cardiac response has been hypothesized to be an index of the psychostimulant properties of alcohol and of dopamine activation (Conrod et al., 2001), and therefore a marker of vulnerability to addiction. Our findings, although in a small number of subjects, lend support to this theory. Moreover, the personality trait of novelty-seeking, of which impulsiveness is one component, has also been linked to both dopamine function (Cloninger, 1994) and to addictive propensity. High scores on the novelty-seeking scale of the TPQ predict later alcoholism (Cloninger et al., 1988) as well as relapse-rate in detoxified alcoholics (Meszaros et al., 1999). Interestingly, in a previous PET study we found that amphetamine-induced dopamine release also targeted the NAc and correlated with novelty-seeking scores (Leyton et al., 2002).

In the current study, we found no correlation between alcohol-induced NAc dopamine release and subjective measures of intoxication. Previously, we similarly found no correlation between amphetamineinduced dopamine release and behavioral effects such as euphoria and excitation (Leyton et al., 2002). The association between a drug's euphorigenic quality and dopamine release has not been established in humans; similarly, in rats the behavioral significance of increased DA remains a subject of debate. Our failure to find a correlation between subjective effects and DA release likely reflects the fact that alcohol acts on mul- tiple neurotransmitter systems. In particular, the SHAS mostly reflects the sedative effects of alcohol (Conrod et al., 2001), which are probably not mediated by dopamine.

In conclusion, we showed that alcohol consumed by mouth in intoxicating doses promotes dopamine release in the ventral striatum. The observed relationship between the magnitude of change in $\left[{ }^{11} \mathrm{C}\right]$ raclopride $\mathrm{BP}$, personality, and heart rate increase suggests that the paradigm we have developed could be used to investigate the factors that lead to vulnerability for alcohol dependence.

\section{REFERENCES}

Acquas E, Meloni M, Di Chiara G. 1993. Blockade of delta-opioid receptors in the nucleus accumbens prevents ethanol-induced stimulation of dopamine release. Eur J Pharmacol 230:239-241.

Aston JA, Gunn RN, Worsley KJ, Ma Y, Evans AC, Dagher A. 2000. A statistical method for the analysis of positron emission tomography neuroreceptor ligand data. Neuroimage 12:245-256.

Benjamin D, Grant ER, Pohorecky LA. 1993. Naltrexone reverses ethanol-induced dopamine release in the nucleus accumbens in awake, freely moving rats. Brain Res 621:137-140.

Carson RE, Breier A, de Bartolomeis A, Saunders RC, Su TP, Schmall

B, Der MG, Pickar D, Eckelman WC. 1997. Quantification of amphetamine-induced changes in [11C]raclopride binding with continuous infusion. J Cereb Blood Flow Metab 17:437-47.

Cloninger CR. 1994. Temperament and personality. Curr Opin Neurobiol 4:266-273.

Cloninger CR, Sigvardsson S, Bohman M. 1988. Childhood personality predicts alcohol abuse in young adults. Alcohol Clin Exp Res 12:494-505.

Cloninger CR, Przybeck TR, Svrakic DM. 1991. The tridimensional personality questionnaire: U.S. normative data. Psychol Rep 69: 1047-1057.

Collins DL, Neelin P, Peters TM, Evans AC. 1994. Automatic 3D intersubject registration of $\mathrm{MR}$ volumetric data in standardized Talairach space. J Comput Assist Tomogr 18:192-205.

Conrod PJ, Peterson JB, Pihl RO. 2001. Reliability and validity of alcohol-induced heart rate increase as a measure of sensitivity to the stimulant properties of alcohol. Psychopharmacology 157:2030.

Diana M, Pistis M, Muntoni A, Rossetti ZL, Gessa G . 1992. Marked decrease of A10 dopamine neuronal firing during ethanol withdrawal syndrome in rats. Eur J Pharmacol 221:403-404.

Di Chiara G, Imperato A. 1988. Drugs abused by humans preferentially increase synaptic dopamine concentrations in the mesolimbic system of freely moving rats. Proc Natl Acad Sci 85:5274-5278.

Di Chiara G, Tanda G, Bassareo V, Pontieri F, Acquas E, Fenu S, Cadoni C, Carboni E. 1999. Drug addiction as a disorder of associative learning. Role of nucleus accumbens shell/extended amygdala dopamine. Ann NY Acad Sci 877:461-485.

Drevets WC, Gautier C, Price JC, Kupfer DJ, Kinahan PE, Grace AA, Price JL, Mathis CA. 2001. Amphetamine-induced dopamine release in human ventral striatum correlates with euphoria. Biol Psychiatry 49:81-96

Endres CJ, Kolachana BS, Saunders RC, Su T, Weinberger D, Breier A, Eckelman WC, Carson RE.. 1997. Kinetic modeling of [11C]raclopride: combined PET-microdialysis studies. J Cereb Blood Flow Metab 17:932-942.

Everitt BJ, Morris KA, O'Brien A, Robbins TW. 1991. The basolateral amygdala-ventral striatal system and conditioned place preference: further evidence of limbic-striatal interactions underlying rewardrelated processes. Neuroscience 42:1-18.

Gatto GJ, McBride WJ, Murphy JM, Lumeng L, Li TK. 1994. Ethanol self-infusion into the ventral tegmental area by alcohol-preferring rats. Alcohol 11:557-564.

Gessa GL, Muntoni F, Collu M, Vargiu L, Mereu G. 1985. Low doses of ethanol activate dopaminergic neurons in the ventral tegmental area. Brain Res 348:201-203.

Ginovart N, Farde L, Halldin C, Swahn CG. 1997. Effect of reserpineinduced depletion of synaptic dopamine on [11C]raclopride binding to D2-dopamine receptors in the monkey brain. Synapse 25:321325 . 
Gonzales RA, Weiss F. 1998. Suppression of ethanol-reinforced behaviour by naltrexone is associated with attenuation of the ethanolinduced increase in dialysate dopamine levels in the nucleus accumbens. J Neurosci 18:10663-10671.

Grace AA, Bunney BS. 1985. Opposing effects of striatonigral feedback pathways on midbrain dopamine cell activity. Brain Res 333 271-284.

Gunn RN, Lammertsma AA, Hume SP, Cunningham VJ. 1997. Parametric imaging of ligand-receptor binding in PET using a simplified reference region model. Neuroimage 6:279-287.

Haber SN, Fudge JL, McFarland NR. 2000. Striatonigrostriatal path ways in primates form an ascending spiral from the shell to the dorsolateral striatum. J Neurosci 20:2369-2382.

Hartvig P, Torstenson R, Tedroff J, Watanabe Y, Fasth KJ, Bjurling P, Langstrom B. 1997. Amphetamine effects on dopamine release and synthesis rate studied in the rhesus monkey brain by positron emission tomography. J Neural Transm 104:329-339.

Heimer L, Switzer RD, Van Hoesen GW. 1982. Ventral striatum and ventral pallidum. Components of the motor system? Trends Neurosci 5:83-87.

Hiroi N, White NM. 1991. The amphetamine conditioned place preference: differential involvement of dopamine receptor subtypes and two dopaminergic terminal areas. Brain Res 552:141-152.

Hooks MS, Colvin AC, Juncos JL, Justice Jr JB, 1992. Individual differences in basal and cocaine-stimulated extracellular dopamine in the nucleus accumbens using quantitative microdialysis. Brain Res 587:306-312.

Judd LL, Hubbard B, Janowsky DS, Huey LY, Attewell PA. 1977. The effect of lithium carbonate on affect, mood, and personality of normal subjects. Arch Gen Psychiatry 34:346-351.

Katner SN, Weiss F. 1999. Ethanol-associated olfactory stimuli reinstate ethanol-seeking behavior after extinction and modify extracellular dopamine levels in the nucleus accumbens. Alcohol Clin Exp Res 23:1751-1760.

Koepp MJ, Gunn RN, Lawrence AD, Cunningham VJ, Dagher A, Jones T, Brooks DJ, Bench CJ, Grasby PM. 1998. Evidence for striatal dopamine release during a video game. Nature 393:266268

Koob GF, Sanna PP, Bloom FE. 1998. Neuroscience of addiction Neuron 21:467-476.

Lammertsma AA, Hume SP. 1996. Simplified Reference Tissue Model for PET Receptor Studies. Neuroimage 4:153-158.

Laruelle M. 2000. Imaging synaptic neurotransmission with in vivo binding competition techniques: a critical review. J Cereb Blood Flow Metab 20:423-451.

Laruelle M, Iyer RN, al-Tikriti MS, Zea-Ponce Y, Malison R, Zoghbi SS, Baldwin RM, Kung HF, Charney DS, Hoffer PB, Innis RB, Bradberry CW. 1997. Microdialysis and SPECT measurements of amphetamine-induced dopamine release in nonhuman primates. Synapse 25:1-14

Leyton M, Boileau I, Benkelfat C, Diksic M, Baker G, Dagher A. 2002. Amphetamine-induced increases in extracellular dopamine, drug wanting and novelty seeking: A PET/[11C]raclopride study in healthy men. Neuropsychopharmacology 27:1027-1035.

Marinelli M, White FJ. 2000. Enhanced vulnerability to cocaine selfadministration is associated with elevated impulse activity of midbrain dopamine neurons. J Neurosci 20:8876-8885.

Martinez D, Slifstein M, Broft A, Mawlawi O, Hwang DR, Huang Y, Cooper T, Kegeles L, Zarahn E, Abi-Dargham A, Haber SN, Laruelle M. 2003. Imaging human mesolimbic dopamine transmission with positron emission tomography. II. Amphetamine-induced dopamine release in the functional subdivisions of the striatum. J Cereb Blood Flow Metab 23:285-300.

Mereu G, Gessa GL. 1985. Low doses of ethanol inhibit the firing of neurons in the substantia nigra, pars reticulata: a GABAergic effect? Brain Res 360:325-330.

Meszaros K, Lenzinger E, Hornik K, Fureder T, Willinger U, Fischer G, Schonbeck G, Aschauer HN. 1999. The Tridimensional Personality Questionnaire as a predictor of relapse in detoxified alcohol dependents. The European Fluvoxamine in Alcoholism Study Group. Alcohol Clin Exp Res 23:483-486.
Moore RY, Bloom FE. 1978. Central catecholamine neuron systems: anatomy and physiology of the dopamine systems. Annu Rev Neurosci 1:129-169.

Nowak KL, McBride WJ, Lumeng L, Li TK, Murphy JM. 2000. Involvement of dopamine D2 autoreceptors in the ventral tegmental area on alcohol and saccharin intake of the alcohol-preferring $\mathrm{P}$ rat. Alcohol Clin Exp Res 24:476-483.

Piazza PV, Rouge-Pont F, Deminiere JM, Kharoubi M, Le Moal M, Simon H. 1991. Dopaminergic activity is reduced in the prefrontal cortex and increased in the nucleus accumbens of rats predisposed to develop amphetamine self-administration. Brain Res 567:169174.

Pokorny AD, Miller BA, Kaplan HB. 1972. The brief MAST: a shortened version of the Michigan Alcoholism Screening Test. Am J Psychiatry 129:342-345.

Rassnick S, Stinus L, Koob GF. 1993. The effects of 6-hydroxydopamine lesions of the nucleus accumbens and the mesolimbic dopamine system on oral self-administration of ethanol in the rat. Brain Res 623:16-24.

Rossetti ZL, Hmaidan Y, Gessa GL. 1992. Marked inhibition of mesolimbic dopamine release: a common feature of ethanol, morphine, cocaine and amphetamine abstinence in rats. Eur J Pharmacol 221:227-234.

Samson HH, Hodge CW, Tolliver GA, Haraguchi M. 1993. Effect of dopamine agonists and antagonists on ethanol-reinforced behaviour: the involvement of the nucleus accumbens. Brain Res Bull 30:133-141.

Schlaepfer TE, Pearlson GD, Wong DF, Marenco S, Dannals RF. 1997. PET study of competition between intravenous cocaine and [11C]raclopride at dopamine receptors in human subjects. Am J Psychiatry 154:1209-1213.

Schuckit MA, Tipp JE, Smith TL, Wiesbeck GA, Kalmijn J. 1997. The relationship between self-rating of the effects of alcohol and alcohol challenge results in ninety-eight young men. J Stud Alcohol 58:397404.

Stormark KM, Laberg JC, Bjerland T, Nordby H, Hugdahl K. 1995. Autonomic cued reactivity in alcoholics: the effect of olfactory stimuli. Addict Behav 20:571-584

Talairach J, Tournoux P. 1988. Co-planar stereotaxic atlas of the human brain. Stuttgart: Thieme.

Tremblay RE, Pihl RO, Vitaro F, Dobkin PL. 1994. Predicting early onset of male antisocial behaviour from preschool behaviour. Arch Gen Psychiatry 51:732-739.

Volkow ND, Wang G, Fowler JS, Logan J, Gerasimov M, Maynard L, Ding Y, Gatley SJ, Gifford A, Franceschi D. 2001. Therapeutic doses of oral methylphenidate significantly increase extracellular dopamine in the human brain. J Neurosci 21:RC121.

Weiner JL, Zhang L, Carlen PL. 1994. Potentiation of GABAA-mediated synaptic current by ethanol in hippocampal CA1 neurons: possible role of protein kinase C. J Pharmacol Exp Ther 268:13881395.

Weiss F, Lorang MT, Bloom FE, Koob GF. 1993. Oral alcohol selfadministration stimulates dopamine release in the rat nucleus accumbens: genetic and motivational determinants. J Pharmacol Exp Ther 267:250-258.

Weiss F, Parsons LH, Schulteis G, Hyytia P, Lorang MT, Bloom FE, Koob GF . 1996. Ethanol self-administration restores withdrawalassociated deficiencies in accumbal dopamine and 5-hydroxytryptamine release in dependent rats. J Neurosci 16:3474-3485.

Wise RA. 1996. Neurobiology of addiction. Curr Opin Neurobiol 6:243-251.

Woods RP, Mazziotta JC, Cherry SR. 1993. MRI-PET registration with automated algorithm. J Comput Assist Tomogr 17:536-546.

Yim HJ, Schallert T, Randall PK, Gonzales RA. 1998. Comparison of local and systemic ethanol effects on extracellular dopamine concentration in rat nucleus accumbens by microdialysis. Alcohol Clin Exp Res 22:2367-2374.

Zocchi A, Orsini C, Cabib S, Puglisi-Allegra S. 1998. Parallel straindependent effect of amphetamine on locomotor activity and dopamine release in the nucleus accumbens: an in vivo study in mice. Neuroscience 82:521-528. 